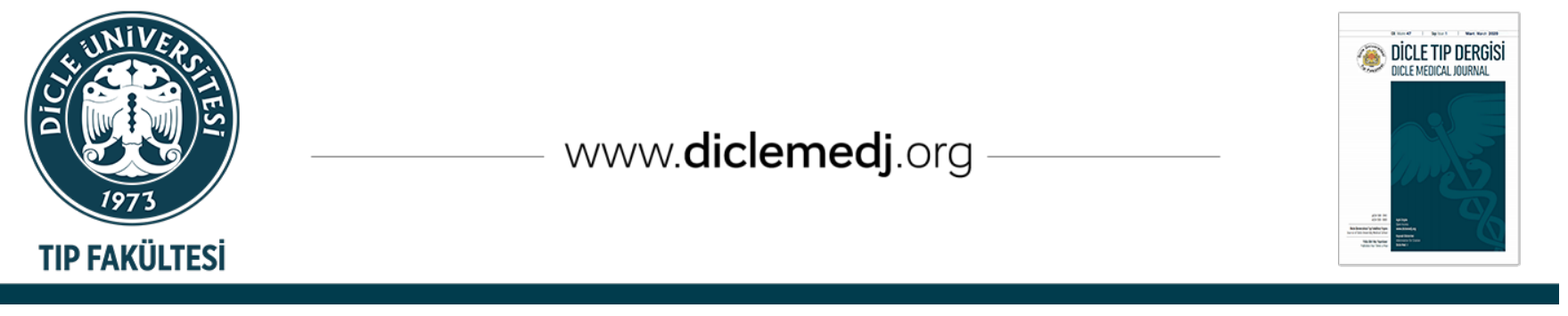

Özgün Araștırma / Original Article

\title{
Multipl Skleroz'de Yaşam Kalitesi: Depresif Bulgular Fiziksel Özürlülük Kadar Etkili midir?
}

\author{
Mesrure Köseoglu ${ }^{D}$ 1, R. Gökçen Gözübatik Çelik ${ }^{D}$ 1, Mesude Tütüncü iD 1, Bahar Erbaş ${ }^{\text {iD } 2,3}$ \\ 1 Sağlık Bilimleri Üniversitesi, Bakırköy Prof. Dr. Mazhar Osman Ruh Sağlığı ve Sinir Hastalıkları Eğitim ve Araştırma Hastanesi, Nöroloji \\ Bölümü, İstanbul, Türkiye
}

2 Demiroğlu Bilim Üniversitesi Tıp Fakültesi, Farmakoloji Anabilim Dalı, İstanbul, Türkiye

3 İstanbul Florance Nightingale Hastanesi, Nöroloji Kliniği, İstanbul, Türkiye

Geliș: 06.07.2020; Revizyon: 31.08.2020; Kabul Tarihi: 04.09.2020

Öz

Amaç: Multipl Sklerozda (MS) yaşam kalitesinin bozulması tedavi uyumunu ve klinik takibi güçleştirir. Çalışmamızda hastaların yaşam kalitesine etki eden faktörlerden fiziksel nedenler ile psikolojik olarak en fazla gözlenen depresif bulgular arasında karşılaștırma yaparak, bu konunun önemini vurgulamayı amaçladık.

Yöntemler: Mc Donalds kriterlerine göre relapsing-remitting tanısı almış 100 hasta çalışmaya dahil edildi. Sosyodemografik özellikleri, hastalık başlangıç yaşları, hastalık süreleri, özürlülük düzeyleri, Beck Depresyon Ölçeği, Yorgunluk Şiddet Ölçeği ve Kısa Form Yaşam Kalitesi Ölçeği skorları kaydedildi.

Bulgular: 65'i kadın, 35'i erkek 100 hastanın yaş ortalaması 35,21 \pm 8,86 (min-max:18-63) yıldı. Ortalama Krutzke Genişletilmiş Dizabilite Durum Skalası (EDSS) skorları 1,65 \pm 1,47 (min-max:0-6,5) olarak kaydedildi. Beck Depresyon Ölçeği skorları kadınlarda erkeklere göre daha yüksek gözlendi $(13,8 \pm 11,02$ vs 10,17 $\pm 6,15$; p:0,036). Depresyonu olan hastaların depresyonu olmayanlara göre; yorgunluk șiddet ve yorgunluk etki ölçeği skor ortalamaları daha yüksekken, yașam kalitesi ölçeği skorları daha düșük izlendi $(\mathrm{p}<0,001)$. Depresyon varlığının ve EDSS skorlarının yaşam kalitesi skorlarına etkisi incelendiğinde, yaşam kalitesi ölçeği ile EDSS skorları arasında istatistiksel açıdan anlamlı negatif yönlü orta şiddette bir ilişki gözlendi $(r=-0,508 ; p<0,001)$. Yaşam kalitesi ile depresyon skorları arasında istatistiksel açıdan anlamlı negatif yönlü orta şiddette bir ilişki saptandı $(r=-0,507 ; p<0,001)$.

Sonuç: MS hastalarının fiziksel özürlülüğü nedeniyle ortaya çıkan yaşam kalitesi bozukluğu benzer şekilde depresif bulgular için de geçerlidir. Sonuçlarımız fiziksel özürlülük oluşmaması için gereken özenin (tedavi seçimi, yeni tedavi arayışları gibi) depresif bulgular için de gösterilmesi ve multipl skleroz hastasına multidisipliner yaklaşımın gerekliliğini bir kez daha ortaya koymuştur.

Anahtar kelimeler: multipl skleroz, yaşam kalitesi, EDSS, depresyon, yorgunluk

\section{DOI: 10.5798/dicletip.800284}

Correspondence / Yazışma Adresi: Rabia Gökçen Gözübatık Çelik, Sağlık Bilimleri Üniversitesi, Prof Dr. Mazhar Osman Ruh Sağlı̆̆ı ve Sinir Hastalıkları Eğitim ve Araştırma Hastanesi Nöroloji Bölümü, İstanbul, Türkiye e-mail: gokcen3@hotmail.com 


\title{
Quality of Life in Multiple Sclerosis: Are Depressive Findings as Effective as Physical Disability?
}

\begin{abstract}
Objective: Impairment of multiple sclerosis (MS) life make it difficult to comply with treatment and the clinical follow-up. In our study we emphasized the importance of this problem, compared with the most common depressive results the physical factors that affect the quality of life for patients.

Methods: 100 patients were included in the study who were diagnosed with re-transmission in accordance with Mc Donalds criteria. Social demographic properties, age, duration of the disease, levels of disability, Beck Depression Scale, Fatigue Severity Scale and Life Scale Short Form Quality were recorded.

Results: The mean age was 35,21 \pm 8,86 (min-max:18-63) years for 100 patients, 65 females and 35 males. Approximately $1.65 \pm 1.47$ Expanded Disability Status Scale (EDSS) scores (min-max. 00-6.5) were recorded. In women the rate of Beck Depression was higher than in men $(13.8 \pm 11.02$ vs $10.17 \pm 6.15$; p: 0.036$)$. The mean measures of fatigue severity and tiredness were higher, but the scale of the quality of life was lower $(\mathrm{p}<0.001)$ according to patients with no depression. On the basis of a statistically significant negativemoderate relationship between the quality of life scale and EDSS scores $(r=-0.508 ; p<0.001)$ when depression and EDSS scores were evaluated. The negative correlation between quality of life and depression values was statistically significant ( $\mathrm{r}=-0.507 ; \mathrm{p}<0.001$ ).

Conclusion: For depressive findings, the quality of life disorder caused by MS patients are equally valid. Once again, our results have shown the need to ensure that depressive observations are avoided (such as medication availability, the need for a new procedure) and that a multidisciplinary approach is needed for patients with multiple sclerosis.
\end{abstract}

Keywords: multiple sclerosis, quality of life, EDSS, depression, fatigue.

\section{GíRiş}

Multipl Skleroz (MS) genç yaşta özürlülüğe neden olan kronik enflamatuar demiyelinizan bir nörolojik hastalıktır. Genç yaşta mesleki ve sosyal sorunlarla da ömür boyu mücadele etmek zorunda kalan MS hastalarının yaşam kalitesi hem hastalığın yükü hem de sosyal nedenlerle ciddi oranda etkilenir.

Yakın geçmişe kadar, MS hastalarının değerlendirilmesinde daha çok muayene ve laboratuvar bulguları ön planda tutulmuştur. Hem hastalığın getirdiği fizyolojik problemler hem de tedavilerin yöntem sıklık ve yan etkileri hastaların yaşam kalitesini olumsuz etkilemektedir. Fiziksel özürlülüğün yaşam kalitesi puanlarındaki olumsuz etkisi birçok çalışmada bildirilmiştir. Ancak güncel çalışmalarda MS hastalarındaki yaşam kalitesini etkileyen faktörlerin bu kadarla sınırlı olmadığı anlaşılmıştır. Ülkemizde MS hastalarıyla sağlıklı kontrollerin karşılaştırıldığı çalışmalarda depresif bulguların $(\% 53,7)$ kontrollere göre $(\% 9,3)$ daha yüksek olduğu ortaya konmuștur; depresyonu olan grupta yaşam kalitesi skorlarının daha düşük izlendiği gözlenmiștir.
$\mathrm{Bu}$ nedenle sadece MS 'i tedavi ederek özürlülüğü azaltmak bu konuda yetersiz kalınmasına neden olmaktadır. Ancak, klinisyenlerce fiziksel özürlülük daha ön planda değerlendirildiği için genellikle pratikte psikososyal faktörler ihmal edilmektedir ${ }^{1-3}$.

Hastaların yaşam kalitelerinin bozulması ile gelen ek tablolar hastaların hem tedavi uyumunu hem klinik takiplerini zorlaştırır. Bu nedenle MS hastalarına multisistemik yaklaşmak hem klinisyenin tedavi başarısını hem de hastaların birçok faktörle ilişkili olan yaşam kalitesini arttırmaya yardımcı olur.

Literatür incelendiğinde ülkemizde MS ve yaşam kalitesiyle ilgili farklı metodolojide yapılan birçok çalışma bulunmaktadır ${ }^{3-7}$. Çalışmamızda hastaların yaşam kalitesine etki eden faktörlerden fiziksel nedenler ile psikolojik olarak en fazla gözlenen depresif bulgular arasında karşılaştırma yapılarak, hastalara multisistemik yaklaşımın öneminin vurgulanması amaçlanmıştır. 


\section{YÖNTEMLER}

Çalıșmaya Ocak 2019- Ocak 2020 tarihleri arasında hastanemiz nöroloji polikliniğinden MS polikliniğine sevk edilen ve Mc- Donald 2017 kriterlerince kesin relapsing remitting MS tanısı alan,498 hastadan düzenli takibe gelen ve gönüllü olarak çalışmaya katılan ve uygulanan anketleri tam olarak dolduran 100 hasta dahil edildi. Hastaların sosyodemografik özellikleri, hastalık başlangıç yaşı, hastalık süresi, özürlülük düzeyi (Expanded Disability Status Scale, EDSS) excel formatına kaydedildi. Tüm hastalara aynı gün içinde aynı kişi gözetiminde Beck Depresyon Ölçeği (BDÖ), Yorgunluk Şiddet Ölçeği (YŞÖ), Yorgunluk Etki Ölçeği (YEÖ), Kısa Form Yaşam Kalitesi Ölçeği (KF-36) uygulandı. Ölçekler excel formatına kaydedildi.

Antidepresan ilaç kullanan, depresyona neden olabilecek diğer nörolojik ve psikiyatrik hastalıkları olan, son üç ay içinde atak geçiren 18 yaş altı hastalar çalışmaya dahil edilmedi.

Kullanılan Ölçekler

Krutzke Genişletilmiş Dizabilite Durum Skalası, (Expanded Disability Status Scale, EDSS): $\mathrm{Bu}$ skala MS hastalarının nörolojik muayenelerine dayalıdır, birçok alt fonksiyonların değerlendirilerek özürlülük göstergesi olarak kullanılır. Bu ölçekte 0 (yetersizlik yok) ile 10 (MS'e bağlı ölüm) arasında 20 basamak bulunmaktadır ${ }^{8}$.

Beck Depresyon Ölçeği (BDÖ), (Beck Depression Inventory, BDI): MS hastalarında depresyon taraması için önerilmektedir. 21 sorudan oluşur. 18 ve üzerindeki puanlar orta ve ileri derecede depresyonun göstergesi olarak kabul edilir. Türkçe geçerlilik ve güvenirliliği Hisli ve ark. tarafından yapılmıştır 9 .

Yorgunluk Şiddet Ölçeği (YŞö), (Fatigue Severity Scale, FSS): Yorgunluk değerlendirmesinde türkçe geçerlik ve güvenirliği gösterilmiştir ${ }^{10}$. Hastaların kendi kendine uygulayabileceği 9 maddeden oluşan ölçekte, her madde 1-7 arasında (1=hiç katılmıyorum, 7=tamamıla katılıorum) skorlanır ve toplam skor 9 maddenin ortalaması alınarak hesaplanır. Patolojik yorgunluk için kesme değeri 4 ve üstü kabul edilir. Toplam skor ne kadar düşükse yorgunluk o kadar azdır.
Yorgunluk Etki Ölçeği (YEÖ), (Fatigue İmpact Scale, FíS): FíS, yorgunluğun fiziksel, bilişsel ve sosyal etkilerini ölçen çok boyutlu bir ölçektir. 10'u bilişsel, 10'u fiziksel ve 20'si sosyal alt ölçeklerle ilgili 40 sorudan oluşmaktadır. Her soru 1'den 4'e kadar puan alır ve minimumdan ciddi dereceye değişir. En yüksek toplam puan 160'tır. MS hastalarında güvenilirlik ve geçerliliği kanıtlanmıştır ${ }^{11}$.

Kisa Form-36 (KF-36), (Short Form-36, SF-36): Yaşam kalitesini değerlendirmede Türkçe geçerlik çalışması yapılmış olan ve oldukça yaygın kullanılan bir ölçüttür ${ }^{12}$. Fiziksel fonksiyon, fiziksel rol kısitlanması, emosyonel rol kısitlanması, vücut ağrısı, sosyal fonksiyon, mental sağlık, canlılık, genel sağllk olmak üzere 8 alt bölümde toplam 36 soru içerir. Fiziksel komponent ve mental komponent olmak üzere iki bölümü vardır. 100 üzerinden yapılan skorlamada yüksek skorlar sağlıkta daha iyi bir düzeyi işaret ederken düşük skorlar sağlıktaki bozulmayı göstermektedir.

\section{İstatistiksel İnceleme}

Veriler IBM SPSS V23 ile analiz edildi. Normal dağılıma uygunluk Kolmogorov Smirnov ve ShapiroWilk testleri ile incelendi. Tanımlayıcı istatistikler ortalama \pm Standart sapma (SD) (minimummaksimum) şeklinde, kategorik değişkenler ise olgu sayısı (n) ve yüzde (\%) olarak gösterildi.-Gruplara göre kategorik değişkenlerin karşılaştırılmasında Ki-kare ve Fisher's Exact testleri kullanıldı. İkili gruba göre nicel değişkenlerin karşılaştırılmasında normal dağılan veriler için Bağımsız iki örnek t testi ve normal dağılmayan veriler için Mann-Whitney U testi kullanıldı. Üç ve üzeri gruplara göre nicel değişkenlerin karşılaştırılmasından normal dağılan veriler için tek yönlü varyans (ANOVA) analizi ve normal dağılmayan veriler için Kruskal Wallis testi kullanıldı. Nicel veriler arasındaki ilişkiyi ölçmede normal dağılım göstermeyen veriler için Spearman's rho korelasyon katsayısı kullanıldı. Herbir değişkene ait odds oranı ve \%95 güven aralıkları hesaplandı. $\mathrm{p}<0.05$ için sonuçlar istatistiksel olarak anlamlı kabul edildi.

Örneklem Büyüklüğü ve Güç Analizi: Çalışmada geçerliliği sınanacak temel hipotezler için ilişkisel analizler için korelasyon analizi grup karşılaştırmaları için ise bağımsız örneklem testi 
kullanılmıştır. T testinde büyük düzeyde etki büyüklügü hedeflemesine göre $(\mathrm{r}=.80), \alpha$ hata olasılığ 0,05 ve $1-\beta$ hata olasılığ belirlenerek G-Power 3.0.10 programı ile gerekli minimum örneklem sayısı hesaplanmıştır. Depresyon varlığı/yokluğu için, grup oranları 1'e 2 olarak belirlenmiş (Depresyon olmayan grup n, depresyon olan grup 2n) ve 63'e 31 kişilik gruplarla yapılacak karşılaștırmada kritik t:1.986 olarak belirlenmiş ve bu 94 kişilik çalışmanın. 95034 güce sahip olacağı saptanmıştır. Bu bilgiler ışığında; çalışmaya 100 kişi dâhil edilmiş ve depresyon varlığı/yokluğu oranı kısmen korunmuştur $(81,19)$. Bu grup sayılarına göre analizlerin kritik t: 1.285 ve 87622 gücünde olduğu belirlenmiş ve iki grup karşılaștırmalarında gerekli olan ve hedeflenen etki/güç büyüklüğü elde edilmiştir. Demiroğlu Bilim Üniversitesi Klinik Araştırmalar Etik Kurulu'ndan 23.06.2020 tarihinde 2020/11-1 numara ile etik kurul onayı alınmıştır.

\section{BULGULAR}

65'i kadın 100 RRMS hastası çalışmaya dahil edildi. Hastaların ortalama yaşı 35,21 \pm 8,86 (min-max:1863) yıldı. Kadınların ortalama yaşı $34,49 \pm 9,42$ (min-max:18-63) yll iken, erkeklerin 36,54 \pm 7,66(min-max:22-50) yll olarak hesaplandı. 56 (\%56) kişinin ilk ve ortaokul mezunu, 37 (\%37) hastanın aktif çalışmakta olduğu gözlendi. Ortalama hastalık süresi 6,87 \pm 4,97 (min-max:0.42-22) yll, ortalama atak sayıs 3,98 \pm 3,2 (min-max:1-18) saptandl. Ortalama EDSS skorları ise 1,65 \pm 1,47(min-max:0-6,5) olarak izlendi.

Ölçek puanları değerlendirildiğinde 100 RRMS hastasının ortalama KF-36 ortalaması 96,09 \pm 9,72 (min-max:72-114) iken, YŞÖ ortalaması 38,13 \pm 15,47 (min-max:11 -63), YEÖ ortalaması 85,62 \pm 27,88 (min-max:31-154), BDÖ ortalaması 12,58 \pm 9,78 (min-max:0-51) saptandı. BDÖ skorları kadınlarda erkeklere göre daha yüksek izlendi $(13,8$ $\pm 11,02$ vs $10,17 \pm 6,15$; p:0,036). Depresyonu olmayan hastaların \%61,4'ü kadın iken \%38,6'sı erkek ve depresyonu olanların \%85,7'si kadın iken $\% 14,3$ 'ü erkekti. Diğer skorlamalarda cinsiyet açısından anlamlı istatiksel bir fark gözlenmedi $(\mathrm{p}>0.05)$.

Hastalık süresi ve yaş açısından değerlendirildiğinde ölçek ortalamalarında anlamlı bir fark izlenmezken, yüksekokul mezunu olanların YEÖ skor ortalamalarının okur yazar ve ilkokul mezunu olanlardan düşük olduğu saptandı $(\mathrm{p}=0.037)$.

Hastalar depresyonu olan (n:21) ve olmayan (n: 79) şeklinde iki gruba ayrıldığında; depresyon varlığına göre cinsiyetin dağılımları arasında istatistiksel olarak anlamlı bir farklılık izlendi $(p=0,036)$. Depresyon olmayan hastaların \%61,4'ü kadın iken $\% 38,6$ 'sı erkek ve depresyonu olanların \%85,7'si kadın iken \%14,3'ü erkek olarak izlendi ( $p>0,050)$ (Tablo 1). Depresyon varlığı ile diğer sosyodemografik özellikler karşılaştırıldığında (medeni hal, eğitim durumu, hastalık süresi) herhangi bir ilişki gözlenmedi ( $p>0.05)$. Ayrıca, depresyonu olan hastaları depresyonu olmayanlara göre; YŞÖ skoru, YŞÖ skoru ortalamaları daha yüksek iken, KF-36 skorları daha düşüktü $(p<0,001)$ (Tablo 2).

Tablo I: Sosyodemografik özelliklerin depresyon varlığına göre karşılaştırılması

\begin{tabular}{|c|c|c|c|c|}
\hline & $\begin{array}{c}\text { Depresyonu } \\
\text { olmayan } \\
\text { [n] [\%] }\end{array}$ & $\begin{array}{c}\text { Depresyonu } \\
\text { var } \\
\text { [n] [\%] }\end{array}$ & $\begin{array}{l}\text { Toplam } \\
\text { [n] [\%] }\end{array}$ & $\mathrm{p}$ \\
\hline \multicolumn{5}{|l|}{ Cinsiyet [n] [\%] } \\
\hline Kadın & $51(61,4]$ & $18[85,7]$ & $69[66,3]$ & \multirow{2}{*}{$0,036^{*}$} \\
\hline Erkek & $32[38,6]$ & $3[14,3]$ & $35[33,7]$ & \\
\hline \multicolumn{5}{|l|}{ Medeni durumu[n] [\%] } \\
\hline Bekar & $24[28,9]$ & $6[28,6]$ & $30[28,8]$ & \multirow{2}{*}{$0,975^{*}$} \\
\hline Evli & $59[71,1]$ & $15[71,4]$ & $74[71,2]$ & \\
\hline \multicolumn{5}{|l|}{ Eğitim düzeyi [n] [\%] } \\
\hline Okur yazar ve İlkokul & $33[40,2]$ & $9[42,9]$ & $42[40,8]$ & \multirow{4}{*}{$0,811^{*}$} \\
\hline Ortaokul & $14[17,1]$ & $4[19]$ & $18[17,5]$ & \\
\hline Lise & $20[24,4]$ & $6[28,6]$ & $26[25,2]$ & \\
\hline Yüksekokul & $15[18,3]$ & $2[9,5]$ & $17[16,5]$ & \\
\hline \multicolumn{5}{|l|}{ Yaș grup [n][\%] } \\
\hline $18-28$ & $22[26,5]$ & 4 [19] & $26[25]$ & \multirow{3}{*}{$0,119 *$} \\
\hline $29-38$ & $31[37,3]$ & $13[61,9]$ & $44[42,3]$ & \\
\hline$>38$ & $30[36,1]$ & 4 [19] & $34[32,7]$ & \\
\hline \multicolumn{5}{|c|}{$\begin{array}{l}\text { Hastalık süresi grup [yıl] } \\
{[\mathrm{n}][\%]}\end{array}$} \\
\hline$<5$ yll & $19[35,8]$ & $8[61,5]$ & $27[40,9]$ & \multirow{3}{*}{$0,206^{*}$} \\
\hline 5-10 yıl & $19[35,8]$ & $2[15,4]$ & $21[31,8]$ & \\
\hline$>10$ yll & $15[28,3]$ & $3[23,1]$ & $18[27,3]$ & \\
\hline
\end{tabular}

${ }^{*}$ Ki-kare testi, ${ }^{* *}$ Fisher's Exact testi 
Tablo II: Depresyonun yaş, hastalık süresiyle ilişkisi; EDSS ve diğer test skorlarına etkisi

\begin{tabular}{|c|c|c|c|c|c|}
\hline Test & & Depresyonu olmayan & Depresyonu var & Toplam & $\mathrm{p}$ \\
\hline \multirow{2}{*}{ EDSS } & Ort. \pm S. sapma & $1,58 \pm 1,36$ & $1,89 \pm 1,83$ & $1,65 \pm 1,47$ & \multirow{2}{*}{$0,927^{*}$} \\
\hline & Ort. [Min. - Maks.] & $1,5[0-6]$ & $1[0-6,5]$ & $1,5[0-6,5]$ & \\
\hline \multirow{2}{*}{ BDÖ } & Ort. \pm S. sapma & $8,63 \pm 5,25$ & $28,19 \pm 7,67$ & $12,58 \pm 9,78$ & \multirow{2}{*}{$<0,001^{* *}$} \\
\hline & Ort. [Min. - Maks.] & $9[0-16]$ & $27[18-51]$ & $11,5[0-51]$ & \\
\hline \multirow{2}{*}{ Yorgunluk şiddet } & Ort. \pm S. sapma & $34,94 \pm 14,81$ & $51,74 \pm 10,05$ & $38,13 \pm 15,47$ & \multirow{2}{*}{$<0,001^{* *}$} \\
\hline & Ort. [Min. - Maks.] & 31 [11 - 63] & $54[26-63]$ & 38 [11 - 63] & \\
\hline \multirow{2}{*}{ Yorgunluk etki } & Ort. \pm S. sapma & $78,9 \pm 24,97$ & $112,86 \pm 21,26$ & $85,76 \pm 27,78$ & \multirow{2}{*}{$<0,001 * *$} \\
\hline & Ort. [Min. - Maks.] & $76[31-154]$ & 109 [81 - 151] & $83[31-154]$ & \\
\hline \multirow{2}{*}{ KF36 yaşam kalitesi } & Ort. \pm S. sapma & $97,45 \pm 9,5$ & $89,81 \pm 10,21$ & $95,9 \pm 10,08$ & \multirow{2}{*}{$0,002^{* *}$} \\
\hline & Ort. [Min. - Maks.] & 99 [73 - 114] & 90 [64 - 108] & $96[64-114]$ & \\
\hline \multirow{2}{*}{ Yaş } & Ort. \pm S. sapma & $35,17 \pm 9,22$ & $35,86 \pm 9,07$ & $35,31 \pm 9,15$ & \multirow{2}{*}{$0,760^{* *}$} \\
\hline & Ort. [Min. - Maks.] & 35 [18 - 63] & $35[22-60]$ & 35 [18 - 63] & \\
\hline \multirow{2}{*}{ Hastalık süresi [Yıl] } & Ort. \pm S. sapma & $7,05 \pm 4,73$ & $5,77 \pm 5,95$ & $6,79 \pm 4,97$ & \multirow{2}{*}{$0,411^{* *}$} \\
\hline & Ort. [Min. - Maks.] & $7[0,42-22]$ & $3[1-20]$ & $6[0,42-22]$ & \\
\hline
\end{tabular}

*Mann-Whitney U testi, **Bağımsız iki örnekt testi BDÖ: Beck Depresyon Ölçeği KF-36: Kısa Form-36

Depresyon varlığının ve EDSS skorlarının SF-36 skorlarına etkisi araştırıldığında ise, SF-36 yaşam kalitesi puanı ile EDSS skoru arasında istatistiksel açıdan anlamlı negatif yönlü orta şiddette bir ilişki gözlendi $(r=-0,508 ; p<0,001)$. SF-36 yaşam kalitesi puanı ile BDÖ skoru arasında istatistiksel açıdan anlamlı negatif yönlü orta şiddette bir ilişki saptandı ( $\mathrm{r}=-0,507$; $\mathrm{p}<0,001$ ), (Tablo 3).

Tablo III: EDSS ve Depresyon skorlarının yaşam kalitesine etkisi

\begin{tabular}{|c|c|c|}
\hline \multirow[b]{3}{*}{ EDSS } & \multicolumn{2}{|c|}{ KF-36 Yaşam Kalitesi } \\
\hline & $\mathrm{r}$ & \\
\hline & $-0,508$ & $<0,001$ \\
\hline BDÖ & $-0,507$ & $<0,001$ \\
\hline
\end{tabular}

BDÖ: Beck Depresyon Ölçeği KF-36: Kısa Form-36

\section{TARTIŞMA}

MS hastalığında fiziksel özürlülüğün yaşam kalitesi üzerine olumsuz etkisi aşikardır. Ancak çalışmamız EDSS' nin yaşam kalitesi üzerine etkisiyle benzer bir diğer faktörün depresif bulgular olduğunu ve depresif bulguların diğer etkenlerden bağımsız olarak fiziksel özürlülügün olumsuz etkisine benzer şekilde hastaların yaşam kalitesini etkileyebildiğini ortaya koymuştur. Ayrıca, depresif bulguların sıklıkla kadın MS hastalarında ortaya çıktığını ve yorgunluk şiddet skorları benzer olmasına rağmen yine kadınların erkeklere göre yorgunluk etkisini daha fazla yaşadıkları gözlenmiştir $(\mathrm{p}<0.01)$.

MS hastalarının hem sağlıklı kişilere hem de diyabet, epilepsi gibi diğer kronik hastalıkları olanlara göre daha fazla yaşam kalitelerinin etkilendiği bilinmektedir ${ }^{13}$. Multisistemik kronik bir hastalık olan MS için yaşam kalitesini etkileyen fiziksel, psikososyal birçok faktör olduğu bildirilmiștir. Örneğin, \%66,9'unun RRMS tanısı aldığı 260 MS hastasında yapılan güncel bir çalışmada EDSS-fiziksel özürlülüğün yaşam kalitesini olumsuz etkilediği bildirilmiștir ${ }^{14}$. Yine ülkemizde 104 MS 
hastasında ağrının yorgunluk, depresyon ve yaşam kalitesi üzerine etkisinin araştırıldığı bir diğer çalışmada da ağrı varlığına bakılmaksızın tüm MS hastalarının yaşam kalitesinin düşük olduğu tespit edilmiştir ${ }^{15}$. Çalışmamızdaki sonuçlar da literatürü destekler özelliktedir.

Kronik bir hastalı olan MS'de depresyon toplum temelli yapılan iki ana çalışmaya göre $\% 41,0$ ve $\% 25,7$ olarak tespit edilmiş ve ayrıca MS'de depresyonun 12 kat artabileceği bildirilmiştir ${ }^{16-18}$. Ülkemizde Onat ve ark.' larının 54 MS hastasında yaptıkları çalışmada ise MS 'de depresif bulguların kontrollere göre daha yüksek olduğunu ortaya koymuşlar $(\% 53,7 / \% 9,3)$ ve MS'de 5,7 kat depresif bulguların arttığını göstermişlerdir. Farklı metodolojide ülkemizde yapılan bir çalışmada da ağrılı MS hastalarında daha belirgin olmak üzere MS hastalarında depresif bulguların fazla gözlendiğine ve yaşam kalitesini önemli olarak olumsuz etkilediğine dikkat çekilmiştir ${ }^{14,15}$. Altmış iki MS hastasının sağlıklı kontrollerle karşılaştırıldığı bir diğer çalışmada da MS tipi, cinsiyet, hastalık süresi faktörlerinden daha çok depresyon varlığının yaşam kalitesini etkilediği bildirilmiştir ${ }^{19}$. Benzer sonuçlara ulaștığımız 100 RRMS'in incelendiği çalışmamızda da depresyonu olan ve olmayan MS hastaları arasında cinsiyet hariç (kadınlarda daha sık) diğer sosyodemografik özellikler açısından (eğitim durumu, meslek, medeni durum, hastalık tipi ve hastalık süresi) farklılık olmaması, depresyonu olan MS hastalarında yaşam kalitesinin depresyonu olmayanlara göre daha düşük izlenmesi, literatürle uyumluluk göstermektedir ${ }^{3,20,21 . ~}$

Ancak 2006 ve 2009 yıllarında MS hastaları üzerinde yapılan çalışmalarda hastalık süresi ve yaşam kalitesinin negatif yönlü ilişkili olduğu izlenmiş, hastalık süresi arttığında özürlülük artacağı ve yaşam kalitesi etkileneceği belirtilmiştir. Ancak güncel çalışmalarda böyle bir ilişki saptanmamıștır ${ }^{14-19}$. Günümüzde MS hastalığına olan farkındalığın ve hastaların tedaviye uyumlarının artması, yeni tedavi seçenekleri ile atak sıklıklarının ve kısmen de özürlülüklerinin azalması ile bu ilişkinin ortadan kalktığı düşünülmüştür22,23.

Yakın dönemde yapılan çalışmalarda yaşam kalitesinin fonksiyonel durumla ilişkisi olmadığı bildirilmekle birlikte kötü fonksiyonel durumun depresyona yatkınlık oluşturduğunu söyleyen yayınlar da mevcuttur ${ }^{24,25}$. Chen ve ark. depresyonun yaşam kalitesini bozduğunu ve özellikle depresyonun mental kapasite üzerine olumsuz etkileri olduğunu vurgulamışlardır ${ }^{26}$. Literatürde EDSS ile değerlendirilen nörolojik fonksiyon bozukluğu ile depresyon ilişkisinin araştırıldığı birçok makalede negatif yönlü anlamlı bir ilişki izlenmiştir18,20,26. Ayrıca çalışmalarda KF-36 ölçeği ile değerlendirilen yaşam kalitesi skorlarının EDSS ve BDÖ skorlarıyla istatistiksel olarak anlamlı düzeyde ilişkili olduğu gösterilmiştir ${ }^{4,14}$. Çalışmamızda MS hastalarında fiziksel özürlülüğün yaşam kalitesine olumsuz etkisine benzer şekilde depresif bulguların da bu konuda negatif şekilde rol oynadığı gözlenmiş, hastalara multidispiliner yaklaşımın önemi ortaya konulmuştur ( $\mathrm{p}>0.001$ ve $\mathrm{r}=-0.508)$.

Multipl Sklerozlu hastalarda yorgunluk \%70 oranında sıkça gözlenir. Etyolojisinde beyin lezyonları ve psikolojik faktörler rol alır. Yapılan araştırmalarda yorgunluğun depresyon, anksiyete ve özürlülükle pozitif ilişkili ve hayat kalitesini de olumsuz etkilediği gösterilmiștir13,14,27,28. MS'de yaşam kalitesi ölçeği-54 (MSQoL-54) anketi kullanılarak 103 MS'li hastada depresyon ve yorgunluğun hayat kalitesi üzerine etkisi araştırılmış EDSS ile orta düzeyde ilişki izlenirken depresyonla daha güçlü bir ilişki gözlenmiştir. Ayrıca yorgunluk depresyon ve özürlülüğün MS hastalarında yaşam kalitesini etkileyen bağımsız risk faktörleri olduğu belirtilmiştir ${ }^{29}$. Sonuçlarımızda EDSS ve BDÖ skorlarının benzer korelasyonla MS hastalarının yaşam 
kalitelerini etkilediği ve depresyonu olan grupta YŞÖ ve YEÖ skorlarının daha yüksek olduğu gösterilmiştir $(\mathrm{p}<0.01)$.

Çalışmamızın kısıtlılığı olarak hastaların tek bir merkezle sınırlı kalmasını bildirebiliriz ancak hastanemiz MS polikliniklerinde hem il içi hem il dışı birçok hasta düzenli takiplerle nöroloji uzmanlarımızca kontrol edilmektedir.

Sonuç olarak çalışmamızda iki dikkat çeken bulgu izlenmiştir. Yorgunluk şiddet puanları benzer olmasına rağmen yorgunluk etki ortalamalarının kadın MS vakalarında daha fazla olduğu ve depresyonun fiziksel özürlülükle aynı korelasyonda hayat kalitesini olumsuz etkileyerek bağımsız bir risk faktörü olduğu gözlenmiştir.

Merkezimizde de uygulandığı gibi, klinisyenlerin hastaların sadece nörolojik şikayetlerini değerlendirmeyip ürolojik, cinsel, psikolojik gibi ek sorunları ilgili birimlerle koordineli çalışması, hastanın yaşam kalitesini olumlu yönde etkileyecek ve bu durum tedavi başarısını, hasta hekim ilişkisini kuvvetlendirecektir.

Özetle, multifaktöryel etkileșimi olan MS hastalarının fiziksel özürlülüğü nedeniyle ortaya çıkan yaşam kalitesi bozukluğu benzer şekilde depresif bulgular için de geçerlidir. Sonuçlarımız fiziksel özürlülük oluşmaması için gereken özenin (tedavi seçimi, yeni tedavi arayışları gibi) depresif bulgular için de gösterilmesi ve MS hastalarına multidisipliner yaklaşımın gerekliliğini ortaya koymuştur.

Etik Kurul Kararı: Demiroğlu Bilim Üniversitesi Klinik Araştırmalar Etik Kurulu'ndan 23.06.2020 tarihinde 2020/11-1 numara ile etik kurul onayı alınmıştır.

Çıkar Çatışması Beyanı: Yazarlar çıkar çatışması olmadığını bildirmişlerdir.

Finansal Destek: Bu çalışma her hangi bir fon tarafından desteklenmemiştir.
Declaration of Conflicting Interests: The authors declare that they have no conflict of interest.

Financial Disclosure: No financial support was received.

\section{KAYNAKLAR}

1. Bilgi E, Özdemir HH, Bulut S. Multipl sklerozlu hastalarda depresyon ve kognitif fonksiyon bozukluğu sıklığının belirlenmesi. Türk Nörol Derg. 2013; 19: 11-4.

2. Mavioğlu H, Tülek Z, Bakar E, Tavşanlı NG. Multiple Sklerozda Yaşam Kalitesi ve Ölçümü. Türk Nörol. Derg. 2014; 1: 18-23.

3. Onat ŞŞ, Delialioğlu SÜ, Özel S. Multipl Sklerozda depresyon, fonksiyonel durum ve yaşam kalitesi ilişkisi: Bir rehabilitasyon merkezi deneyimi. FTR Bil Der. 2015; 18: 139-45.

4. Baumstarck K, Boyer L, Boucekine M, Michel P, Pelletier J, Auquier P. Measuring the Quality of Life in Patients with Multiple Sclerosis in Clinical Practice: A Necessary Challenge. Multiple Sclerosis International Volume 2013 (2013), Article ID 524894, 8 pages

5. Güler BS, Ersin F. Multiple skleroz hastalarinin yaşam kalitesi ve ruhsal durumları Anadolu Hemşirelik ve Sağlık Bilimleri Dergisi. 2018; 21: 4250 .

6. Aygünoğlu SK, Çelebi A, Vardar N, Gürsoy E. Multıpl skleroz hastalarında yorgunluğun depresyon, özürlülük ve yaşam kalitesi ile ilişkisi. Arch Neuropsychiatr. 2015; 52: 247-51.

7. Güven ŞŞ, Özcan DS, Aras M, Köseoğlu BF, Ak F. Multipl sklerozlu hastalarda ağrının değerlendirilmesi ve yaşam kalitesi, yorgunluk ve depresyon ile ilişkisi. Turk J Phys Med Rehab 2016; 62: 123-31.

8. Kurtzke JF. Rating neurologic impairment in multiple sclerosis: An Expanded Disability Status Scale (EDSS). Neurology. 1983; 33: 1444-52.

9. Hisli N. Beck Depresyon Envanteri'nin geçerliği üzerine bir çalışma. Psikoloji Dergisi 1988; 6: 11826. 
10. Armutlu K, Korkmaz NC, Keser I, et al. The validity and reliability of the Fatigue Severity Scale in Turkish multiple sclerosis patients. Int J Rehabil Res. 2007; 30: 81-5

11. Fisk JD, Ritvo PG, Ross L, Haase DA, Marrie TJ, Schlech WF. Measuring the functional impact of fatigue: initial validation of the fatigue impact scale. Clinical Infectious Diseases, 1994; 18: 79-83.

12. Koçyiğit H, Aydemir Ö, Fişek G, Ölmez N, Memiş A. Kısa Form-36 (KF-36)' nın Türkçe versiyonunun Güvenilirliği. İlaç ve Tedavi Dergisi 1998; 12: 102-6.

13. Kidd T, Carey N, Mold F, et al. A systematic review of the effectiveness of self-management interventions in people with multiple sclerosis at improving depression, anxiety and quality of life. PLoS ONE 12: e0185931.

14. Schmidt S, Jöstingmeyerb P. Depression, fatigue and disability are independently associated with quality of life in patients with multiple Sclerosis: Results of a cross-sectional study. Multiple Sclerosis and Related Disorders 2019; 35: 262-9.

15. Güven ŞŞ, Özcan DS, Aras M, ve ark. Multipl sklerozlu hastalarda ağrının değerlendirilmesi ve yaşam kalitesi, yorgunluk ve depresyon ile ilişkisi. Turk J Phys Med Rehab 2016; 62(2): 123-31.

16. Chwastiak L, Ehde DM, Gibbons LE, et al. Depressive symptoms and severity of illness in multiple sclerosis: and epidemiologic study of a large community sample. Am J Psychiatry 2002; 159: 1862-8.

17. Patten SB, Beck CA, Williams JV, et al. Major depression in multiple sclerosis: a population based perspective. Neurology 2003; 61: 1524-7.

18. Tanık N, Aydın A, Selvi Y, ve ark. Multipl sklerozda tedavi, özürlülük ve depresyon arasındaki ilişki. Nöropsikiyatri Arşivi 2012; 49: 300-3.

19. Koçer E, Koçer A, Yaman M, ve ark. Multipl Skleroz Olgularında Yaşam Kalitesi: Fiziksel
Özürlülük ve Depresyonun Etkisi?. Journal of Mood Disorders 2011; 1: 63-7.

20. Bilgi E, Özdemir HH, Bulut S. Multipl sklerozlu hastalarda depresyon ve kognitif fonksiyon bozukluğu sıklığının belirlenmesi. Türk Nörol Derg. 2013; 19: 11-4.

21. Soyuer F, Ünalan D, Mirza M. Multipl sklerozda depresif semptomlar; sosyodemografik faktörler ve işlevsellik ile ilişkisi. Türk Nörol Derg. 2010; 16: 315.

22. Yıldız H, İçağasığlu A, Canik N, ve ark. Multipl sklerozda yaşam kalitesi Göztepe Tıp Dergisi. 2006; 20: 36-9.

23. Haliloğlu S, İçağasığlu A, Baklavacıoğlu HŞ, ve ark. Multipl Sklerozda yașam kalitesinin fonksiyonel durum ile ilişkisi Göztepe Tıp Dergisi. 2009; 24: 129 33.

24. McGuigan C, Hutchinson M. Unrecognised symptoms of depression in a community-based population with multiple sclerosis. J Neurol. 2005; 253: 219-23.

25. Kikuchi H, Mifune N, Niino M, et al. Structural equation modeling of factors contributing to quality of life in Japanese patients with multiple sclerosis. BMC Neurol. 2013; 13: 10.

26. Chen K, Fan Y, Hu R, Yang T, Li K. Impact of depression, fatigue and disability on quality of life in Chinese patients with multiple sclerosis. Stress Health 2013; 29: 108-12.

27. Bakshi R, Shaikh ZA, Miletich RS, et all. Fatigue in multiple sclerosis and its relationship to depression and neurologic disability. Mult Scler. 2000; 6: 181-5.

28. Iriarte J, Subira ML, Castro P. Modalities of fatigue in multiple sclerosis: correlation with clinical and biological factors. Mult Scler. 2000; 6: 124-30.

29. Janardhan V, Bakshi R. Quality of life in patients with multiple sclerosis: the impact of fatigue and depression. J Neurol Sci. 2002; 205: 51-8. 